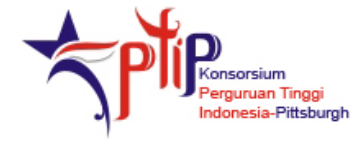

\title{
Opportunities and Obstacles: Technology's Potential for Expanding Access to Higher Education
}

\author{
Rebecca Clothey, ${ }^{\mathrm{a},}$ \\ ${ }^{a}$ Drexel University, USA
}

\begin{abstract}
Innovative technologies have forever impacted the field of education by connecting any topic in any discipline to any learner in any place. This new reality provides vastly expanded possibilities for international collaboration, knowledge building, sharing of best practices, and new ways to teach, both within the classroom and without. Nevertheless, even as new modes of providing education proliferate, the digital divide also grows, making technology solutions for expanding access a continuing issue of debate. This article looks at trends and challenges for expanding access to higher education via technology. Specifically it will address how the role of infrastructure, fiscal restraints, and culture relate to differences in accessibility and the application of technology in higher education. Through an overview of current use of technologies in differing educational contexts, the article analyzes some examples that either support or oppose the idea of promoting technology as an effective tool for facilitating equality of access.
\end{abstract}

\begin{abstract}
Abstrak
Perkembangan teknologi inovatif telah lama menunjukkan kontribusinya di bidang pendidikan dengan merelasikan berbagai topik dan kajian teknologi, faktor siswa dan konteks lingkungan. Realita ini membuka peluang luas bagi kolaborasi internasional, pengembangan ilmu, pertukaran praktik pembelajaran, serta teknik mengajar di dalam dan diluar kelas. Walaupun banyak bermunculan beragam sarana pembelajaran, media digital juga makin berkembang, menjadikan teknologi sebagai solusi memperluas akses perguruan tinggi yang masih terus bermasalah. Makalah ini mengamati tren dan tantangan pengembangan akses pendidikan tinggi melalui teknologi. Secara spesifik, tulisan ini membahas pengaruh kultur, infrastuktur, dan kendala keuangan terhadap perbedaan aksesibilitas dan aplikasi teknologi pada unit pendidikan tinggi. Dari pembahasan singkat penggunaan teknologi dewasa ini di konteks-konteks pendidikan yang berbeda, makalah ini menganalisa beberapa ilustrasi yang dapat menunjang maupun menghambat upaya mempromosikan teknologi sebagai sarana efektif dalam memfasilitasi persamaan akses.
\end{abstract}

Key Words: Higher Education, Digital Divide, Technology, Distance Learning, Mobile Learning

\section{Introduction}

From a personal, national, or global perspective, education is crucial to both human and economic development. Higher education has been identified in nations around the world as a means by which to develop the local human resources and skilled expertise needed to drive economic development. At the same time, the global recession has led to increasing numbers of people who would otherwise be working full-time into post-secondary

*Corresponding author. Address: Drexel University, Goodwin College of Professional Studies, School of Education, 3001 Market Street, Ste. 148, Philadelphia, PA 19104, USA.

Email: rac52@drexel.edu. education. Estimates are that the number of students seeking access to higher education will increase to 159 million by 2025 (Dabbagh and Benson 2007). This recognition has driven governments and institutions to place higher education as a top priority. However, urban poor, rural, and ethnic minority students in both developed and developing countries continue to be underrepresented in tertiary education.

As the global commitment to educational access has become enshrined in all levels of society, new technologies have also been developed that hold tremendous promise for expanding higher education's reach. Not surprisingly, the simultaneous demand for higher education and the potential of technology to expand education access beyond borders has led to the development of new and innovative ways to deliver educational programming. 
Distance learning, open source courseware, e-books, wikis, and many other innovative technologies have forever impacted the field of education by connecting any topic in any discipline to any learner in any place. This new reality provides vastly expanded possibilities for international collaboration, knowledge building, sharing of best practices, and new ways to teach, both within the classroom and without. Nevertheless, even as new modes of providing education proliferate, the digital divide also grows, making technology solutions for expanding access a continuing issue of debate.

This article will look at trends and challenges for expanding access to higher education via technology. Specifically it will address how the role of infrastructure, fiscal restraints, and culture relate to differences in accessibility and the application of technology in higher education. Through an overview of current use of technologies in differing educational contexts, the article will analyze some examples that either support or oppose the idea of promoting technology as an effective tool for facilitating equality of access.

\section{Information and Communication Technology (ICT) and Educational Resources: Opportunities}

Information and Communication Technology (ICT) has had a profound effect on education in recent decades, and legislation concerning technology-based education is now one of the predominant global policy issues across industrialized nations (Selwyn, Gorard, and Williams 2001). Indeed, the potential connection between ICT and national economic development goals has been much touted. International agencies such as the United Nations Development Program (UNDP) promotes ICT as an enabler to address socio-economic concerns, and the United Nations Educational, Scientific and Cultural Organization (UNESCO) advocates ICT for facilitating the modernization of education. Among the more remarkable stories for promoting ICT for development is that of Rwanda, a nation with a per capita income of about US\$290 per year. The Rwandan government's 2000 report Rwanda Vision 2020 proposed to make Rwanda into a technology and communications hub and to use the Internet to transform the country from an agricultural society to a knowledgebased one by the year 2020. Since then Rwanda has constructed approximately 2,300 kilometers of optical fiber cable network across the country. The cost of the fiber optic cable network for this low-income nation was approximately US\$95 million (Fiber Optic Mania 2011), an investment which demonstrates a firm belief in the ability of the Internet to promote national development.
Internet technology has been particularly advocated for its potential for broadening the reach of education and expanding school access beyond the brick and mortar confines of schools. In fact, the Internet as a means of delivering distance education has increased 40 percent annually, and the governments of many countries have supported distance education as a means of promoting greater educational access (Clothey 2008). This in turn has opened up new opportunities for universities to recruit from a new population of students that they might otherwise not have reached.

International students who can access courses online no longer must wait for increasingly difficult to obtain visas or seek financial support for foreign living expenses. In this way, online learning might serve to eliminate the brain drain over the longer term as an educated-elite develop foreign credentials without leaving their home country. Distance learning's potential to recruit from a larger student population also increases opportunities for universities facing state-level financial cuts to develop new revenue sources. In fact, Latchem (2005) proposes that most tertiary institutions develop online programming because of financial ambitions, despite a rhetoric that may emphasize international cooperation.

The growth in online distance learning as a viable means of educational delivery has coincided with the expansion of technology use across the world. Internet World Stats (2010) reports that there was a 444.8 percent growth in Internet usage throughout the world during the decade of 2000-2010, with a 77 percent Internet penetration rate across North America in 2010. Currently Asia accounts for 42 percent of the total world Internet usage, and Asia also has the largest number of adult online learners in the world (Latchem and Jung 2010).

Perhaps the most rapid growth of online learning has been in China over the past ten years, with the government encouraging it as a potential means for reaching remote populations and nontraditional students. In 2001, China established online education programs at 31 pilot universities, and the number had more than doubled to 68 universities with online institutes by August 2004. Even some of China's top universities, such as Qinghua, Fudan, Beijing Normal and Peking University offer online programs for non-traditional students. Indeed over ten percent of China's approximately 19 million university students are engaged in online learning (Kang and Song 2007).

Many campus-based universities in China have also started to offer online programs in order to share educational resources. In fact, China's government gives grants worth about US\$10,000 to professors at dozens of universities to help them improve their undergraduate teaching materials and then put them online. The purpose is for less prestigious institutions to benefit from the 
country's best instructors and thus improve their own courses. More than 10,000 courses from Chinese universities are now available online as a result (Ajula and Terris 2009). As of 2008, more than 100 universities worldwide were placing free content online, and 5,000 online classes are now available through institutions in the United States, Japan, Vietnam, and India, to name a few (Bonk 2009).

These trends, as well as pedagogical and technological innovations, have increased the potential for interaction and collaborative work in distance learning. Two movements in particular, the free software and the open source movements, promote the free exchange of technology and of information, and thus have made a multitude of free educational resources available that educators can utilize in their own classrooms as supplemental materials and/or as resources. Free open course management systems provide possibilities for student collaborations across borders.

Specifically, the Free Software Foundation is a non-profit organization that advocates the idea that users should have the freedom to run, copy, distribute, study, change and improve software, and to do so for free. Consequently, the Foundation offers a myriad of free educational resources categorized by subject and education level that can easily be downloaded and utilized either by faculty, as a course supplement, or by students, to enhance their knowledge in a particular subject area.

Similarly, open courseware refers to content being placed on the Internet and made available for free to the general public. This initiative has been led by the Massachusetts Institute of Technology (MIT), which since its inception in 2001 has placed more than 2,000 of its classes online, sharing them with over 100 million individuals. MIT (n.d.) specifically states their goal over the next decade as being "to make open educational resources like MIT OpenCourseWare the tools to bridge the global gap between human potential and opportunity, so that motivated people everywhere can improve their lives and change the world." MIT's OCW materials have also been translated into at least 10 languages, including Spanish, Portuguese, Chinese (simplified and traditional), French, German, Thai, Turkish, Persian, Vietnamese, and Ukrainian. The translated courses are also available for free access.

Open source courseware platforms such as Moodle and Sakai provide a free platform through which institutions and individuals can place course materials online. Because these two platforms enable interactivity between users, many tertiary institutions have adopted one or the other as an inexpensive means of providing online courses, as opposed to using a well-known but fee-based Learning Management System such as Blackboard. As of spring 2011 Moodle (n.d.) claimed 43,019,887 registered users in 212 countries, with 4,528,187 courses and 72,733,537 quiz questions. A glance at Sakai's (n.d.) website reveals that prestigious US universities, including Columbia, Johns Hopkins, and Stanford, are among those institutions utilizing Sakai to support teaching, research, and service.

Commonly used platforms such as YouTube and iTunesU also offer educational videos and podcasts on myriad subjects that are available for free download. In addition, interactive web 2.0 tools make it possible for any individual to add to that database of content at any time.

Finally, videoconferencing software has expanded the realm of live interactions now possible in a classroom. International exchanges can be fostered with a wider range of people and across oceans, without physically crossing a national border. Through videoconferencing it is possible to host virtual live lectures, symposia, and conferences with scholars and professionals throughout the world, without any participant leaving their own home. Drexel University, for example, hosted two virtual symposia, one in 2008 and one in 2010, which produced content by educators, and for educators. The symposia utilized video technology and Moodle to provide synchronous panel discussions and live keynote lectures from international experts based in the US, Austria, the Philippines, China, and Japan. Individuals were able to participate live by simply clicking a link. In addition, the web 2.0 tools enabled interactivity, so participants could also ask questions of the experts, and communicate with other participants via chat modalities. All sessions were also recorded for on-demand playback later.

The diversity of the symposium participants indicates the potential information and communication technologies provide for global collaboration. The 2008 inaugural symposium attracted 240 registrants from 13 countries and five continents. Additionally, while the majority of the participants were native English speakers, participants also specified speaking Chinese, Spanish, Korean or Urdu natively. In sum, it is no longer necessary to fly across an ocean to meet a colleague from an institution in another country.

When asked in a post-symposium survey what factors motivated them to register for the event, the majority ( 90 percent) of respondents cited the content of the panels and lectures. However more than half (52 percent) also indicated they were interested in the virtual format (Clothey and Austin-Li 2009). This suggests that a proportion of the participants might not have attended at all had the event not been offered online.

Such conferences open up a new professional network to individuals, and provide limitless potential guest lecturers from around the world. In an online class, instructors might hail from anywhere, making it possible to draw from the world's top 
expertise. There are other benefits as well. In Saudi Arabia, for example, videoconferencing has enabled female students in schools segregated by gender to interact with male lecturers without being seen by them (Latchem and Jung 2010). In sum, as Bonk $(2009,7)$ extols, "anyone can now learn anything from anyone at anytime." The examples discussed above illustrate that this is indeed true. Nonetheless, it remains true only for individuals that have the appropriate tools by which to do so.

\section{ICT and Infrastructure: Obstacles}

While there is no question that ICT has opened up new opportunities for students and for educators, even the best technology is useless if the infrastructure is poor or if the users have not been adequately trained. Both ICT and Internet availability are inconsistent from one region to another. Of 133 nations ranked according to ICT readiness by the 2009-10 Global Information Technology Report, no countries from South America or Africa were in the top 25 (Dutta and Mia 2010).

Furthermore, although developing countries have 80 percent of the world's population, they have just 5 percent of the world's Internet hosts. In contrast, North America has only 5 percent of the population, and 65 percent of the world's Internet hosts (Bjarnason 2007). In 2007, 83 percent of the world's Internet users were located in Europe, Asia, or North America (Internet World Stats [IWS] 2010). None of the top 20 countries in terms of Internet usage are in Africa, and the top 20 countries combined exceeded the Internet usage of the entire rest of the world (IWS 2010).

In many places, this divide is also prevalent within countries, where rural areas commonly have poorer ICT infrastructure than urban areas. China, for example, had the world's second largest Internet population in 2005, with 103 million users. However, rural users accounted for a mere 1.2 percent of that total (McQuaide 2009). Such disparities are also evident in tertiary education enrollments. While 70 percent of secondary school graduates in Beijing went directly to universities in 2001 (Yang 2002), less than 0.4 percent of Tibetans, who mostly reside in rural western China, complete college (Zhou 2001). This accentuates the issue that online learning cannot provide access to those most in need if there are physical barriers such as a lack of infrastructure to support it.

Information technology has been recognized as a means for sustaining development in India, where there are reportedly four million technology workers. However, the International Energy Agency reported in 2010 that more people in India lack access to electricity than any other nation. A 2001 UNDP report showed a digital divide in India even between states. In 1994 electricity was available to 83 percent of households in Punjab, but only 15 percent of households in West Bengal, and 404 million people nationwide remained without electricity in 2010 (Pearson 2010). In addition, while India claims only 0.37 of the overall population as Internet users, more than three thirds of these users reside in the capital city of New Delhi, or one of India's state capitals. One third of these users are from one of two cities, either New Delhi or Mumbai (Chandrasekhar, Kumar, and Karnik 2004).

There is also a technology divide among users in the United States in terms of income, race, ethnicity, and location. The number of Internet users in the United States increased between the years of 2000-2010 from 44 percent to 77 percent of the population (IWS 2010). Furthermore, according to US Census data, nearly nine-in-ten families earning annual incomes of US $\$ 75,000$ or more reported having at least one computer, and about eight-in-ten had at least one household member who used the Internet at home. However, among family households with incomes below US $\$ 25,000$, the picture is vastly different. Only three-in-ten reported having a computer and about two-in-ten had Internet access (Clothey 2008). A similar gap is evident in Internet use between race and ethnicity in the United States. The U.S. Census Bureau Current Population Survey estimated in 2009 that about 47 percent of Hispanic and 45 percent of African American households still have no Internet access at home, as compared with only 29 percent of White and 19 percent of Asian households without Internet access (Census Bureau for the Bureau of Labor Statistics 2009).

Across Asia-Pacific, ICT and Internet penetration ranges widely. Some countries, such as South Korea, Australia, and Singapore, have revised curriculum across the country to incorporate ICT use. They have also included incentives for professional development and teacher training as a major part of the country's ICT program (UNDP 2001).

However, in much of south and central Asia, ICT use, particularly in educational institutions, is still in its infancy. The overall Internet penetration rate in the region is still at only 15 percent, compared with 30 percent in the rest of the world, and in specific countries usage is even less. Bhutan, which did not have television until 1999, still has Internet access available to only 4.5 percent of the population, and in Nepal only one percent of the population has Internet access (Clothey 2010). Other factors such as government regulations and conflict may also impact the ICT infrastructure. In Myanmar, public Internet access is officially restricted to all but a few individuals and armed conflict has severely hindered Internet development in Afghanistan, Iraq, and East Timor (Latchem and Jung 2010). 


\section{ICT, Language and Cultural Barriers}

There are also other issues of access that even better technology infrastructure and training resources cannot address. Among the most challenging are those related to language and culture. For example, the top two most used languages on the Internet are English and Chinese, together comprising more than half of the total, and 82 percent of all websites are in one of only ten of the world's languages (IWS 2010). However, there are 6,000 languages across the world, and most of these do not appear on the Internet at all.

A 2005 UNESCO study found that 80 percent of all web pages hosted on African domains were written in English. African languages accounted for only about 1.3 percent of the more than 1 million web pages examined in the study. The study also found that some of Africa's major languages were absent from the Internet altogether (Fantognon, Mikami, Paolillo, Pimienta, and Prado 2005). In Southeast Asia the diverse population utilizes some 15-20 different written scripts; in China there are an estimated 80-100 languages, many of which use different scripts or do not have written scripts at all (Clothey 2005). In any case, many of the major software packages are currently incapable of producing letters or characters for some local languages, meaning that providing a culturally relevant curriculum online for a linguistic minority student population may present an impossible challenge to overcome.

Just as research has shown that traditional learning environments may be "sites of struggle for teachers and learners when there is a collision of different cultures," (Uzuner 2009, 2), so, too, do cultural differences impact students' academic performance in online-learning environments. One study on cultural differences in asynchronous online classes revealed, for example, that Arab students intentionally participated less in online discussions than their American peers, in part because of Arab culture's social restrictions on the interactions between genders (Uzuner 2009). Language of instruction also matters. Yet another study cited by Uzuner found that academic success of nonnative English speaking adults undertaking graduate level course work online at a UK-based higher education institution were negatively impacted by their unfamiliarity with the linguistic and academic culture of the UK.

Gender is also important in an online setting. Uzuner (2009) also describes findings that female students' cultural expectations regarding women's roles in the home also limited their learning, participation, and engagement in asynchronous learning environments, regardless of their own ethnic or national background.
Uzuner finds that cultural differences in fact hinder students' success in asynchronous online learning environments, and cause them to experience "feelings of isolation, alienation, and dissonance out of conflict with the dominant educational culture" (5). While these findings also support the research on cultural differences in face-to-face classrooms (see, for example, Spradlin and Parsons 2008), they also contradict common assumptions about online learning. More specifically, they contradict the assumption that online learning is beneficial among socially diverse groups because of the inability within an online course to differentiate students' gender, ethnic or racial differences unless they are explicitly stated (see Clothey 2008).

\section{Education Quality: Obstacles}

These findings also bring forward another concern: scalability. As noted, oftentimes institutions that offer distance delivery view it as a profit-making venture, and in order to maximize profit and efficiency, aim to cater online offerings to as wide an audience as possible. Walsh (2007) notes that this requires removing the cultural specificity of educational content in order to make a course universally applicable and marketable. Some scholars express concern that this approach results in homogenization of educational content or a mass-produced product (Clothey 2008).

In sum, although many online resources reach a vast international audience, they are often not modified to suit the local sites of delivery; indeed, cultural diversity is often unacknowledged in design and content (Walsh 2007). Uzuner (2009) also notes that an awareness of the potential differences between cultures by instructional designers or instructors does not necessarily mean this knowledge will be integrated into the online course design.

When considering issues of access, one must also consider whether greater equity of educational access and equivalent access to quality education are incompatible goals. Altbach (2010) argues that as student populations expand, educational quality declines. A consideration of the University World Rankings reveals that over 50 percent of the top 100-ranked universities worldwide are located in the United States (Times Higher Education 2011). However, tuition costs make American universities inaccessible for the majority, and some of the world's best universities are thus out of reach for all but the elite. In addition, the College Board reports that tuition costs in US tertiary institutions increased by 24 percent at public four-year colleges and universities between the years 2005-2011 and by 17 percent at private four-year colleges and universities in the same period (Baum and Ma 2010). These costs make it less likely that individuals from the poorest nations will have access to some of the world's best universities, even if 
the institution's courses are offered online. Finally, although more online courses are available through US Ivy League institutions than in the past, the tuition free options such as those offered through MIT's OpenCourseWare will never result in a degree, no matter how many of these courses an individual views.

\section{Positive Trends}

On a positive note, the fact that technology is constantly changing means that there continue to be new possibilities for providing educational access. A shift in focus to how best to utilize the technology available in the local context may reframe some of the challenges to surmounting the digital divide.

One technology development that could change the ICT landscape is the use of mobile devices to provide educational content. So called "mobile learning," or "M-learning," makes course-related materials accessible through smart phones, cell phones, or other portable technologies such as iPods or mp3 players.

This means of educational transmission has a great deal of potential because mobile phones are widely used, even in some of the world's poorest and most remote communities. Although Asia has relatively low Internet penetration overall, it has one billion of the world's 2.7 billion mobile users, and the world's fastest growth in number of subscribers.

Cambodia, which is one of the world's least developed nations, has the lowest Internet penetration rate in Southeast Asia and few landlines, but it also has the highest call rates. Cambodia also has the world's highest ratio of telephone users using wireless (Latchem and Jung 2010). Similarly, about one third of the population of the African continent had a mobile phone subscription by 2009 , as opposed to only 8.7 percent using the Internet through desktop computers ( $\mathrm{Ng}$ 'andwe 2010). In fact, a chief executive officer for a telecommunications company based in Kenya claims that Africa is the fastest growing cellular market in the world (Mutume 2003).

M-Learning thus has the potential to provide education through a device that is already commonly in use, even in remote and developing areas. M-learning also might require less training than web-based courses because of the familiarity most users already have with cell phones, the medium of delivery. SMS is already being used to support in-service teacher training in some parts of Africa. For example, when Kenya's Ministry of Education introduced Free Primary Education (FPE) across the country, primary school enrollments increased by between $10-25$ percent, creating an immediate demand for more teachers. One component of the teacher-training program that was developed includes delivering study guide material and class outlines via SMS. The reason for choosing this venue of delivery was that teachers already owned the hardware, and the costs of utilizing it are minimal, thereby creating a sustainable model (Traxler and Leach n.d.).

Institutions in many other countries, including South Africa, China, the US, and the Philippines, are also experimenting with mobile learning. There is no question that technology has tremendous potential for higher education, and the fact that technology is constantly changing means that what we lack today, we will be unable to live without tomorrow. This provides hope that some of the challenges we are currently facing with making education equally accessible through technology will be overcome in the future.

In addition, as new information and communications technologies become more ubiquitous, their prices also decline. For example, while ten years ago the cost of a personal computer was well over US $\$ 1,000$, today it is possible to purchase one for less than US\$500. Continuing price reductions over time are likely for once-cutting edge technologies that become more mainstream, making them affordable for families in lower income brackets.

Another trend that is making a difference is collaborative partnerships between the public and private sector. Many schools with low ICT penetration, for example, have benefited from donated computers through the efforts of corporations such as Siemens (UNDP 2001). International organizations are also supporting the development of ICT infrastructure and promoting online learning. The Green Machine initiative, for example, founded by the non-profit organization One Laptop Per Child and sponsored by the United Nations, aims to provide US\$100 laptops en masse to developing countries (Twist 2005).

The Global Development Learning Network (GDLN) was initiated by the World Bank in 2000 as a global partnership of more than 100 learning centers (GDLN Affiliates) that offer the use of advanced information and communication technologies to people working in development around the world (GDLN n.d.). The GDLN is based at the World Bank Institute in Beijing, China. It works with governments and the non-profit and private sector to organize virtual conferences, hold multi-country dialogues, or offer training courses on development topics.

UNESCO's Bangkok office also has a number of ICT in education projects implemented throughout Asia-Pacific. These include training teachers to utilize and incorporate ICT in their curricula, bridging the within country digital divide, and monitoring and measuring change (UNESCO Bangkok n.d.). 


\section{Conclusion}

As described above, ICT is not a magic bullet that easily transcends existing inequalities related to poverty, class, ethnicity, nationality, locale or other issues. Nevertheless, information and communications technology does provide some possibilities, and there are developing trends that suggest positive change for the future.

Capitalizing on the technologies that are already commonly in use in local communities is imperative. Most nations do not have the financial means to construct US\$95 million worth of fiber optic cable to make Internet access widely available. Even if they did, it would still be necessary to train individuals to use it before educational programming via the new technology could be introduced; and there would be no guarantee the new technology would be accepted within the target community.

In addition, as student populations become more diverse, ICT must be utilized creatively to maintain respect for diverse virtual classroom communities and to build on unique cultural customs and strengths (Wellburn and Claeys 2004; Latchem 2005). Collaborative efforts between diverse communities in designing and implementing educational programming will allow diverse global populations to learn from each other and maximize their respective strengths. More efforts are being made to produce webbased educational materials in multiple languages and more languages are also becoming available through Internet-based translation software. If these trends continue, ICT can promote some greater opportunities for educational access and for international exchange. However, continuing to find ways to maximize the potential of ICT to benefit all users will remain a challenge in the twenty-first century.

\section{References}

Ajula, Simmi, and Ben Terris. 2009. "Around the World, Varied Approaches to Open Online Learning." The Chronicle of Higher Education, October 11.

Baum, Sandy, and Jennifer Ma. 2010. Trends in College Pricing. New York: The College Board. Available online at: http://collegeboard.com. For detailed background data and additional information, please visit http://trends.collegeboard.org.

Bonk, Curtis. 2009. The World is Open: How Web Technology is Revolutionizing Education. San Francisco: Jossey Bass.

Carr-Chellman, Alison A., ed. 2005. Global Perspectives on ELearning: Rhetoric and Reality. London: SAGE Publications.

Census Bureau for the Bureau of Labor Statistics. 2009. "Table 1. Reported Internet Usage for Households, by Selected
Householder Characteristics: 2009." Current Population Survey, October 2009. Washington, DC: U.S. Census Bureau.

Chandrasekhar, C. P., Simran Kumar, and Kiran Karnik. (2004). Regional Human Development Report. Promoting ICT for Human Development in Asia: Realising the Milllennium Development Goals (India). New Delhi, India: National Association of Software and Service Companies/United Nations Development Programme. Available online at: http://unapcict.org.

Clothey, Rebecca. 2005. "China's Policies for Ethnic Minority Studies: Negotiating National Values and Ethnic Identities." Comparative Education Review 49 (3): 389-409.

Clothey, Rebecca. 2008. "Education for Everyone: Expanding Opportunities through Distance Education." Journal of The World Universities Forum 1 (4): 81-87.

Clothey, Rebecca. 2010. "Current Trends in Higher Education: Expanding Access in Asia Pacific through Technology." Comparative \& International Higher Education 2 (1): 3-5.

Dabbagh, Nada, and Angela Benson. 2007. "Technology, Globalization and Distance Education: Pedagogical Models and Constructs." In The SAGE Handbook of Research in International Education, ed. Mary Hayden, Jack Levy, and John Jeff Thompson (pp. 188-198). London: SAGE Publications.

Dutta, Soumitra and Mia, Irene. 2010. The Global Information Technology Report 2009-2010. Geneva: The World Economic Forum.

Fantognon, Xavier, Yoshiki Mikami, John Paolillo, Daniel Pimienta, and Daniel Prado. 2005. Measuring Linguistic Diversity on the Internet. Paris: UNESCO. Available online at: http://unesco.org.

Fiber Optic Mania. 2011. Rwanda Completes 2300km Fiber Optic Cable Network. Scottsdale, AZ: GoDaddy.com, Inc. Available online at: http://fiberopticmania.com.

Fildes, Jonathan. (2007). "\$100 Laptop to Sell to Public." $B B C$ News, September 24. Available online at: www.bbc.co.uk.

Global Development Learning Network (GDLN). n.d. Services How to Work with GDLN. Beijing: GDLN. Available online at: http://www.gdln.org.

Internet World Stats (IWS). 2010. Internet World Stats: Usage and Population Statistics. Bogota, Columbia: Miniwatts Marketing Group. Available online at: http://internetworldstats.com.

Jung, Insung. 2007. "Changing Faces of Open and Distance Learning in Asia." International Review of Research in Open and Distance Learning 8 (1): 1-6.

Kang, Feiyu, and Gilsun Song. 2007. "E-Learning in Higher Education in China: An Overview." E-Learning Initiatives in 
China: Pedagogy, Policy and Culture. Hong Kong: Hong Kong University Press.

Latchem, Colin. 2005. "Towards Borderless Virtual Learning in Higher Education." In Global Perspectives on E-Learning: Rhetoric and Reality, ed. Alison A. Carr-Chellman (pp. 179198). Thousand Oaks, CA: SAGE Publications.

Latchem, Colin, and Insung Jung. 2010. Distance and Blended Learning in Asia. New York: Routledge.

Massachusetts Institute of Technology OpenCourseWare. n.d. The Next Decade of Open Sharing: Reaching One Billion Minds. Cambridge, MA. Available online at: http://ocw.mit.edu.

McQuaide, Shiling. 2009. "Making Education Equitable in Rural China through Distance Learning." The International Review of Research in Open and Distance Learning 10 (1): 1-21.

Moodle. n.d. Moodle Statistics. Perth, Australia. Available online at: http://moodle.org.

Mutume, Gumiasai. 2003. "Africa Takes on the Digital Divide." Africa Recovery 17 (3).

Ng'andwe, Talent. 2010. Mobile Phone Learning on the Move in Africa. eLearning Africa News Portal. Berlin: eLearning Africa. Available online at: http://elearning-africa.com.

Sakai. n.d. Community: Organizations Using Sakai. Ann Arbor, MI: Sakai Foundation. Available online at: http://sakaiproject.org.

Selwyn, Neil, Stephen Gorard, and Sara Williams. 2001. "Digital Divide or Digital Opportunity? The Role of Technology in Overcoming Social Exclusion in U.S. Education.” Educational Policy 15 (2): 258-277.

Sharma, Priya. 2005. "Distance Education and Online Technologies in India." In Global Perspectives on E-Learning: Rhetoric and Reality, ed. Alison A. Carr-Chellman (pp. 52-66). Thousand Oaks, CA: SAGE Publications.

Spradlin, Lynn K. and Parsons, Richard. 2008. Diversity Matters: Understanding Diversity in Schools. Belmont, CA: Thomson Higher Education.

Times Higher Education. 2011. "The World University Rankings 2011-2012." London: Times Higher Education. Available online at: http://timeshighereducation.co.uk.

Twist, Jo. 2005. "UN Debut for \$100 Laptop for Poor." $B B C$ News, November 17. Available online at: http://bbc.co.uk.

United Nations Development Program (UNDP). 2001. Human Development Report 2001: Making New Technologies Work for Human Development. New York: UNDP. Available online at: http://hdr.undp.org.

United Nations Educational, Scientific and Cultural Organization (UNESCO) Bangkok. n.d. “An Integrated Programme.” In ICT in Education. Bangkok: UNESCO Bangkok. Available online at: http://unescobkk.org.
Uzuner, Sedef. 2009. "Questions of Culture in Distance Learning: A Research Review." International Review of Research in Open and Distance Learning 10 (3).

Van Dusen, Gerald. 2000. Digital Dilemma: Issues of Access, Cost, and Quality in Media-Enhanced and Distance Education. San Francisco: Jossey-Bass.

Walsh, Lucas. 2007. "The Future of E-Learning in International Education: Issues, Challenges and Lessons from the Past Two Decades." In The SAGE Handbook of Research in International Education, ed. Mary Hayden, Jack Levy, and John Jeff Thompson (pp. 199-210). London: SAGE Publications.

Wellburn, Elizabeth and Claeys, Gregory. 2004. "CommunityBased Distributed Learning in a Globalized World." In Distance Learning and University Effectiveness: Changing Educational Paradigms for Online Learning, ed. Caroline Howard, Karen D. Schenk, and Richard Discenza (pp. 79-98). Hershey, PA: Idea Group.

Yang, Rui. 2002. "Lost Opportunities in the Massification of Higher Education in China." International Higher Education 28: 16-18.

Zhou, Ming Lang. 2001. "The Politics of Bilingual Education and Educational Levels in Ethnic Minority Communities in China." International Journal of Bilingual Education and Bilingualism 4 (2): 125-149. 